\title{
Corrosion and biocorrosion in carbon steel
}

\begin{abstract}
The present study had as objective to evaluate the corrosion and biocorrosion in carbon steel ASTM A283 immersed in a biphasic system, containing Diesel S10 tap water in proportions of $1: 1$, under static conditions, over 90 days. Scanning electron microscopy (SEM) techniques were used to monitor these processes. The results indicated that there was localized corrosion, especially on surfaces that were immediately below the diesel/water interface, where corrosion products and biofilm adherence were formed. Therefore, the results revealed that the presence of water in the diesel can be an aggravating factor in the processes of corrosion and biocorrosion.
\end{abstract}

Keywords: biocorrosion, carbon steel A283, corrosion, diesel S10, scanning electron microscopyt
Volume 7 Issue 3 - 2018

\section{DM Frazão, IR de Melo, SL Urtiga Filho}

Departamento de Engenharia Mecânica, Universidade Federal de Pernambuco, Brazil

Correspondence: Diana Magalhães Frazão, Departamento de Engenharia Mecânica, Universidade Federal de Pernambuco, Recife, Brazil, Tel + 55 8I 99842-4905,

Email dianalagatha@gmail.com

Received: May 29, 2018| Published: June 12, 2018

\section{Introduction}

The corrosion process in metallic structures and equipment is one of the serious problems that arise in the various industrial sectors. In this process, chemical and electrochemical reactions occur, associated to the medium in which they are in order to degrade the surface of the material, altering the quality of the product. Thus, the durability and performance of metallic materials no longer meet the intended purpose, causing high economic losses and can also cause serious accidents.

Corrosion is a phenomenon that occurs in iron and many ferrous alloys, such as carbon steel when exposed to the atmosphere or submerged in water. These steels are the materials most used by industries in the form of plates, plates, bars, tubes and tanks. ${ }^{2}$

Since the corrosion process is associated with the action of the medium, chemical, physical and biological factors will directly influence the occurrence of this deterioration phenomenon. In the specific case of biological action, a great prominence is given in the industrial sector to the action or action of microorganisms, which may have a direct or indirect participation in the process of corrosion of metallic surfaces. ${ }^{1,3}$ The performance of microorganisms in the corrosion process is referred to as bio-corrosion or microbiologically influenced corrosion (MIC). ${ }^{3}$ In this mechanism, there is the growth of microorganisms, such as bacteria, fungi and/or algae, that participate actively in the process of corrosion of the metal surface, without altering the electrochemical nature of the corrosion process.

By taking into account the most varied means in which microorganism growth can occur, industrial fuel storage tanks have their interior deteriorated through microbiological corrosion. When the fuel is contaminated with water, it allows the action of microorganisms, which occurs mainly at the fuel/water interface. In this region there is an environment conducive to microbial growth, either in the presence of oxygen (aerobic) or in its absence (anaerobes). ${ }^{4}$

Considering these aspects, the objective of this work was to evaluate the corrosion and biocorrosion process on the ASTM A283 carbon steel surface when exposed to the static system, containing Diesel S10 and tap water, in a ratio of 1:1 for a period of 90 days.

\section{Experimental procedure}

For the development of this work, the ASTM A283 carbon steel was used, which followed the ASTM A283-13 standard. ${ }^{5}$ Rectangular test pieces were made with dimensions of $30 \mathrm{~mm} \times 10 \mathrm{~mm} \times 3 \mathrm{~mm}$, with a $6 \mathrm{~mm}$ diameter hole. The blasted test specimens were subjected to the continuous immersion test in static systems containing Diesel S10 and tap water in the same proportions. And they were arranged at the same time in the reactors, where half of each test body was immersed in diesel oil and the other half in water. These static systems correspond to Reactors 1, 2, 3, which were analyzed at times 30,60 and 90 days, respectively. Before the immersion process, the specimens were cleaned according to G1-03. ${ }^{6}$

The morphology of the corrosion and biocorrosion process was investigated through Scanning Electron Microscopy (SEM). The analytical conditions used for SEM with and with biofilm had the following parameters, respectively: acceleration voltage- $15 \mathrm{Kv}$ and $20 \mathrm{Kv}$, working distance $-8.2 \mathrm{~mm}$ and $10.1 \mathrm{~mm}$, detector type backscatter and secondary. After the immersion process, the specimens underwent mechanical scraping and acid etching so that the surface was free of corrosion or biofilm, and then the analysis was performed on the clean surface. Other specimens were metallized with gold, and the products that adhered to the surface were not removed. Thus, the SEM was performed to evaluate the biofilm and corrosion products on the surface.

\section{Results and discussion}

Figure 1 shows the surfaces of the specimens that went through the biphasic immersion process for 30,60 and 90 days, respectively, after the cleaning process. The images correspond to the surfaces that were immersed in the interface between diesel and water, whose deterioration was more intense. The metal surfaces were found to be excavated and furrowed. This behavior suggested the presence of alveolar corrosion mechanisms. ${ }^{1}$

Initially, the metal surface was in direct contact with the electrolyte (water), providing the process of electrochemical corrosion, due to a greater ionic exchange. After 30 days it was possible to observe corrosion and biofilm products adhered to the surface, acting as a protective barrier. In this way, the corrosion was more intense initially, and there was a reduction of the corrosive process over time. Probably, due to the lack of accessibility of the electrolyte to the substrate, due to the deposits of suspended particles, the corrosion products, the microorganisms, which were adhered to the surface, leading to the formation of the biofilm, and consequently, reducing the corrosion 
rate. This same behavior was observed by Oliveira $^{7} \&$ Vieira. ${ }^{8}$

In relation to the regions immersed in oil, it was observed that they were more protected or less deteriorated than the regions immersed in water. Although the oil had a low conductivity, there was a small ion exchange between the medium and the metal surface. Knothe et al., ${ }^{9}$ reported that diesel is composed of sulfur products and has water content, which allows corrosive actions on the substrate. Vieira ${ }^{10}$ supplemented this argument by showing that it was possible for corrosion to occur on the surface of the metal in contact with the oil, as a result of which it promoted a higher solubility of oxygen.

Figure 2 presents images corresponding to the biofilms deposited on the specimens exposed to the water/oil immersion system, at times 30, 60 and 90 days, respectively. Stretches of the surface of the specimens, which suggest to be corrosion products, extracellular polymeric material (MPE) involving some cells, and the presence of microbial forms, which suggest to be isolated bacterial cells, were observed.

Similar results were found by Vieira ${ }^{10}$ in his study on corrosion and biocorrosion in API 5LX60 steel exposed to crude oil and produced water, whose immersion time was 15 and 90 days, resulting in the same detachment and adhesion behavior of new cells, due to the biofilm formation process being dynamic. Their MEV images showed surfaces also worn and with the presence of excavations and furrows. In addition to corrosion products, extracellular polymer material and isolated bacterial cells were observed.

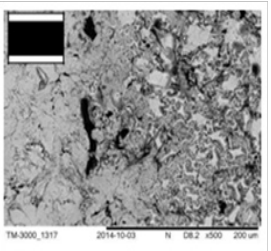

(a)

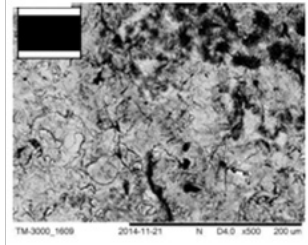

(b)

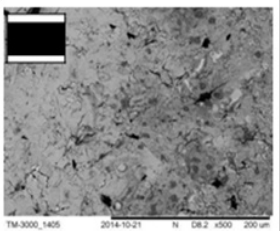

(c)
Figure I Micrograph of the interface deteriorated by the corrosion process, after cleaning (without surface products) (a) after 30 days; (b) after 60 days; (c) after 90 days.

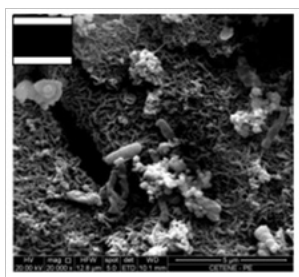

(a)

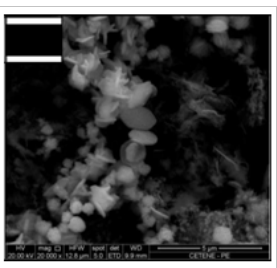

(b)

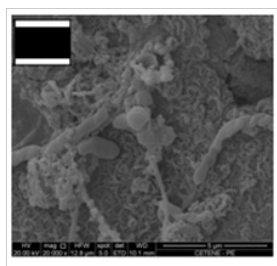

(c)
Figure 2 Micrographies of the surfaces of the test specimens - (a) after 30 days with adherence of MPE, corrosion products and bacterial cells; (b) after 60 days with higher incidence of corrosion products; (c) after 90 days with isolated bacterial cells and MPE.

\section{Conclusion}

The corrosion and biocorrosion behavior of the ASTM A283 carbon steel submitted to the oil/water biphasic immersion system was investigated, and the conclusions obtained showed that SEM images revealed a localized corrosion process, mainly at 30 days. It was also possible to observe a decrease in the corrosion rate during the 90 days of immersion. This factor may be associated with the formation of a layer composed of biofilms adhered to the metallic surface, consisting of corrosion products and forms that suggest to be microbial cells surrounded by extracellular polymeric material. All this material in the surface made difficult the access of the electrolyte to the base metal.

\section{Acknowledgements}

We thank the Universidade Federal de Pernambuco (UFPE), Laboratorio de Materiais Compósitos e Integridade Estrutural (COMPOLAB), Coordenação de Aperfeiçoamento de Pessoal de Nível Superior (CAPES), Conselho Nacional de Desenvolvimento Científico e Tecnológico (CNPq) and Fundação de Amparo à Ciência e Tecnologia de Pernambuco (FACEPE).

\section{Conflict of interest}

The author declares that there is no conflict of interest.

\section{References}

1. V Gentil. Corrosão. Brazil; Rio de Janeiro: 2011.

2. DC Silva, J Johann, MT Cunha, et al. Encontro e Exposição Brasileira de Tratamentos de Superfície. Corrosão em meio diesel do aço carbono revestido com cobre. P. 7.

3. HA Videla. Biocorrosão, biofouling e biodeterioração de materiais. São Paulo, Edgard Blücher: 2003.

4. LC Dias, AR Santos. Corrosão bacteriana em tanques de querosene e gasolina de aviação. Science and Technology. 2012;1(2):76-80.

5. Standard Specification for Low and Intermediate Tensile Strength Carbon Steel Plates. West Conshohocken; ASTM International: 2013.

6. Standard Practice for Preparing, Cleaning, and Evaluating Corrosion Test Specimens. West Conshohocken; ASTM International: 2011.

7. SH Oliveira. Estudo da utilização da xantana e hipoclorito de sódio como estratégia para controle da biocorrosão. Universidade Federal de Pernambuco. 2010

8. MRS Vieira. Estudo dos processos de corrosão e biocorrosão causados por fluidos da indústria de petróleo. Universidade Federal de Pernambuco. 2013.

9. G Knothe, JV Gerpen, J Krahl. Manual de Biodiesel. São Paulo; Edgard Blücher: 2006. 